\title{
The Use of Language Learning Strategies by Iranian Students as Compared to the Learners of Other Ethnic Groups
}

\author{
Ali Mahbudi \\ English Department, Paramedical Sciences Faculty \\ Shiraz University of Medical Sciences, Iran \\ Tel: 98-711-229-4720Ｅ-mail: alimahbudi37@yahoo.com \\ Nasrin Shokrpour (Corresponding Author) \\ English Department, Paramedical Sciences Faculty \\ Shiraz University of Medical Sciences, Iran \\ Tel: 98-711-228-9113Ｅ-mail:shokrpourn@gmail.com \\ Mohammad Rafatbakhsh \\ English Department, Paramedical Sciences Faculty \\ Shiraz University of Medical Sciences, Iran \\ Tel: 98-711-229-4720 E-mail: rafatm0@yahoo.com \\ Zeinab Mahbudi \\ Payam-e-Nour University of Noorabad, Iran \\ Tel: 98-711-229-4720_E-mail: zeinab_meh_1366@yahoo.com
}

Received: Nov. 8, 2012 Accepted: December 6, 2012 Published: February 1, 2013

doi:10.5296/jse.v3i1.2643 URL: http://dx.doi.org/10.5296/jse.v3i1.2643

\begin{abstract}
Research has demonstrated that in addition to such learner variables as intelligence, age, sex, etc., language learning strategies can play some parts in successful language learning. However, language learners are different in their use of such strategies. In spite of some studies in Iran on the use of learning strategy by Iranian learners, to the best of our knowledge, there has not been any research on whether the strategies used by Iranian EFL learners are similar or different from those used by other ethnic groups. So the focus of this
\end{abstract}




\section{Macrothink}

study was to find out whether the type and range of language learning strategies used by Iranian learners are similar to or different from the strategies used by learners from other cultures. To do this, 200 Iranian students (100 studying in high school and 100 at university) were chosen. The Strategy Inventory for Language Learning (SILL version 7 for ESL/EFL learners), a self-report questionnaire, (Oxford, 1990) was used to assess the frequency of learners' strategy use. The findings of this study revealed that Iranian learners used cognitive strategies the most and the affective strategies the least. The comparison revealed that Iranian learners were similar in some respects to and different in some other respects from the language learners of other nationalities in the use of language learning strategies.

Keywords: Language Learning Strategies, Iranian Language Learners, Language Learners of other Nationalities 


\section{Introduction}

Research has demonstrated that in spite of sharing a lot of characteristics such as intelligence, age, sex, etc., some second/foreign language learners are more successful than others. This is also true, no matter what teaching methods or techniques are employed in the class. Researchers have argued that this might be partly due to the strategies the learners use when developing their interlanguage (Griffith \& Parr, 2001). In other words, second/foreign language learners employ some specific behaviors or thought processes consciously or subconsciously in order to enhance their L2 learning and master the nuances and delicacies of the language they are learning. The use of language learning strategies, of course, varies from one learner to the other. That is all learners do not use language learning strategies in the same fashion.

Research on language learning strategies, tracing back to the past thirty years, has revealed the importance of such strategies in making language learning language use (Cohen, 1998; Olivares-Cuhat, 2002; Oxford, 1989). Furthermore, it has been found that these strategies are teachable (Griffith \& Parr, 2001) so that the strategies employed by more successful students can be learnt by those who are less successful.

\subsection{Language Learning Strategies}

Although the core of experts' attitude on language strategies is more or less the same, they have approached the concepts differently and, thus, they have expressed their definitions in their own words. Rubin (1987), for example, argues that language learning strategies are the techniques which contribute to the development of the language system which the learners construct. While Rubin's definition is very general, others offer a more specific definition of such strategies. For instance, Willing (1988, cited in Gardner and Miller 1996) maintains that language strategies are "specific mental procedures for gathering, processing, associating, categorizing, rehearsing and retrieving information and patterned skill.” (p.7) Also, Oxford $(1992,1993)$ argues that language learning strategies are specific actions, behaviors, steps, or techniques that students (often intentionally) use to improve their progress in developing L2 skills.

It follows from such definitions that language learning strategies are specific tools which self-directedly make the students involved in the process of language learning and are necessary for the development of communicative ability. In other words, these strategies can facilitate the internalization, storage, retrieval, and/or use of the new language.

\subsection{Classification of LLSs}

Language learning strategies are broadly divided into direct and indirect strategies (Oxford, 1990). Direct strategies which are subdivided into Memory, Cognitive and Compensation strategies make learners directly involved in the process of language learning. Memory strategies, for example, help the storage and retrieval of new information, while cognitive strategies are employed when the learner intends to understand and/or produce the new language. And the compensation strategies help the learners to fill a gap in knowledge when they communicate.

Indirect strategies, although not directly involving the target language, support the learning process. Such strategies are subdivided into metacognitive, affective and social (Oxford, 
1990). They help the learner to control their own cognition (metacognitive), regulate their emotions and attitudes (affective) and learn through interaction with others (social). Different factors such as personal (age and sex), social, psychological, and cultural affect the use of learning strategies. In this connection, the main purpose of this study is to find out whether Iranian language learners are the same or different in their use of learning strategies. The study, in fact, intends to investigate the role of culture in the use of such strategies. To this purpose, the following research question was posed: Do Iranian language learners use the same or different learning strategies in comparison to their counterparts in other countries?

\subsection{Studies on Language Learning Strategies}

Within the field of foreign language research, a number of studies have shown that learning strategies play an important role in successful language learning. In the last two decades, a lot of studies have been conducted on learning strategies mainly to find out what strategies learners use and prefer, and which factors affect these choices. These studies have revealed that various factors may affect the use of these strategies. (Jafari \& Shokrpour, 2012; Fotovatian \& Shokrpour, 2007; Zarei et al, 2012; Seddigh \& Shokrpour, 2012; Kafipour et al, 2011; Shokrpour \& Nasiri, 2011; Shokrpour \& Mahboudi, 2011).

As Rubin (1987) has pointed out, the use of language learning strategies varies with the task, learning stage, age, context, individual styles and cultural background. Although most of the studies in this area present a greater use of language learning strategies by females, Tran (1988) found that Vietnamese women use much fewer language learning strategies. Also, Sy (1994) found that students of English in the Republic of China showed significant gender differences. In that study, females significantly surpassed males in their use of cognitive, compensation, metacognitive, and social strategies. In another study at three different course levels by Green and Oxford (1995), at the University of Puerto Rico, it was found that females used much more strategies than males and successful learners used more learning strategies.

Cultural background is one of the factors that might influence strategy choice. For example, in an ethnic study among Chinese learners, it was found that students reported a preference for social strategies, but a disinclination to use affective strategies (Tamada, 1996).

Studies on foreign language learning strategies use also show that females use more strategies than males. For example, Oxford et al. (1996, cited in Liu, 2004) found that memory, cognitive and social strategies were dominantly used by female learners in Spanish high schools. And Korean high school female students were found to use five out of six learning strategies (Ok, 2003, cited in Liu, 2004). Bacon and Finnemann (1992) also concluded that females use more social behaviors than males.

Myung-Cook (2001) did a study on language proficiency and the use of language learning strategies by Korean Learners of Chinese. He used the self-rating method and found that social and cognitive strategies were used the most, while affective and memory strategies were used the least. Another study in this field was done by Oktay (2009) at Atilim University of Turkey. The findings revealed that the use of language learning strategies was positively correlated with success in English. It was also found that females used more language learning strategies. 
Regarding the use of language learning strategies by Iranian learners, Amini Farsani, et al. (2011) found that Iranian EFL learners preferred to use metacognitive strategies more frequently than other types of strategies. The subjects of their study were 137 university students majoring in English. In fact, these subjects do not represent a wide range of language learners; something which has been compensated in our study. Other studies (e.g. Kafipour, Yazdani, Soori, \& Shokrpour, 2011) have focused on the use of learning strategy in one specific language skill, for example, reading.

\section{Material and Method}

\subsection{Participants}

200 high school and university students served as the participants of this study. One hundred $10^{\text {th }}, 11^{\text {th }}$ and $12^{\text {th }}$ graders including 50 males and 50 females were selected randomly from 4 high schools in Iran. The other 100 participants were sophomore, junior and senior university students majoring in English. . The choice of such subjects was due to the fact that we could have a wide range of participants with different levels of English proficiency. Furthermore, those majoring in English spend more time on learning this language, so they have to make use of learning strategies more often than the others majoring in other fields which are mostly taught in Persian. The male to female ratio in both high school and university was 1 to 1 .

\subsection{Instruments}

As the data collection instrument, The Strategy Inventory for Language Learning (SILL version 7.0 for ESL/EFL learners), a self-report questionnaire, was used to assess the frequency of the use of language learning strategies (Oxford, 1990). It had been devised in 1985 and later revised by Oxford. It has been used in many studies to determine the use of learning strategies by language learners (Tercanlığlu, 2004).

The SILL uses five Likert-type responses for each strategy item ranging from 1 to 5 (i.e. from 'never or almost never true of me' to 'always true of me'). In the SILL, language learning strategies are grouped into six categories for assessment: Memory, Cognitive, Compensation, Metacognitive, Affective, and Social strategies.

\subsection{Procedure}

The SILL questionnaire, containing 50 items on language learning strategies, was translated into Persian for the high school students since it was thought that some of these students might have problems understanding the original English version. Then the required consent for conducting the research was obtained from the local authorities of education office. Students were, of course, instructed on how to answer the items. The researcher was present during the administration of the tests to explain any ambiguities that might arise. The questionnaire administration took approximately 40 minutes to complete. The same procedure was used for the administration of the questionnaire to the university students except for the fact that the items were not translated into Persian. That is, the original English form was administered to these students. The researcher was, of course, present to explain any possible misunderstanding or ambiguities.

\section{Results and Discussion}

Descriptive statistics and T-test were employed to investigate the overall language learning strategies that Iranian EFL students utilized. 
Table 1. The Use of Strategies by Iranian Students

\begin{tabular}{|l|l|l|l|l|l|}
\hline & N & Minimum & Maximum & Mean & Std. Deviation \\
\hline Memory Strategies & 200 & 14.00 & 44.00 & 26.7050 & 5.62192 \\
\hline Cognitive Strategies & 200 & 22.00 & 66.00 & 43.7100 & 8.64114 \\
\hline Compensation Strategies & 200 & 10.00 & 29.00 & 18.7500 & 4.13558 \\
\hline Metacognitive Strategies & 200 & 11.00 & 44.00 & 30.5500 & 6.46113 \\
\hline Affective Strategies & 200 & 7.00 & 28.00 & 17.4550 & 4.31521 \\
\hline Social Strategies & 200 & 8.00 & 30.00 & 18.8000 & 4.89898 \\
\hline Valid N & 200 & & & & \\
\hline
\end{tabular}

According to the table, Iranian language learners used cognitive strategies more than the other strategies with the mean of 43.7100 , followed by metacognitive, memory, social, compensation and affective strategies with the mean of $30.5500,26.7050,18.8000,18.7500$, and 17.4550, respectively. As shown, they used affective strategies less than other strategies with the mean of 17.4550.The results showed that the use of learning strategies was different in Iranian language learners as compared to the learners from other countries.

The question the study intended to answer was "Is there any difference between strategies used by Iranian language learners and language learners of other countries?" Based on the findings, Iranian EFL learners preferred to use cognitive as the most frequently used language learning strategy and affective as the least frequently used strategy.

The results of the study conducted by Wharton (2000) in Singapore indicated that metacognitive strategies, along with compensation strategies were the most frequently used ones, and memory strategies the least frequently strategies used by adult EFL learners, including those majoring in English and university students in other fields. The findings of Wharton's study have some similarities to those of the present study. In other words, Iranian language learners used cognitive and metacognitive strategies more than the other types of strategies. So it seems that there is no significant difference between Iranian language learners and those from Singapore in their use of language learning strategies. This might be attributed to some similarities in cultural backgrounds as the people in both countries are mostly Moslems and share a lot of religious viewpoints. Other studies showed that the environmental differences could play an important role when learning another language. Still, some studies indicated that the context of language learning is a major factor influencing the choice of language learning strategies.

In Siew-Yen's study (2004), the learners were found to use the compensation strategy most frequently despite their majors, whereas the cognitive strategy was found to be the least type of strategy being used by the learners. The result of Sew Yen's study is not in accordance with the findings of the present study. In fact, there is a complete difference between Chinese and Iranian students in their use of language learning strategies. 
Myung-Cook (2001) showed that the Korean students used social and cognitive strategies the most and the affective and memory strategies the least. He also found that non-Korean learners made use of compensation and metacognitive strategies the most, and affective and memory strategies the least. The findings of the present research showed that Iranian language learners also used cognitive strategies more frequently, while affective strategies were used the least. This is partly similar to what Myung-Cook found in his study.

For the past two decades, because of social and political reasons, Iranian EFL learners have had little or no contact with native speakers of English. In fact, one can rarely find foreign English-speaking nationalities teaching English as a second language (ESL) in Iranian schools or universities, no matter public or private. The use of mass media like Internet and other media, such as satellite TV, is neither widespread nor easily accessible to all language learners. In addition, language teaching during high school years is mostly grammar-based with no attention paid to language use (Rahimi \& Riazi, 2005).

Moreover, the political atmosphere in Iran has witnessed some changes in language teaching. Despite neglecting English and attempting to give more weight to Arabic, many economic, industrial, educational, and military activities in the country still require knowledge of English. Therefore, the concept of learning English as a threat to national and cultural identity has changed (Farhady \& Hedayati, 2009).

On the other hand, in recent years, students have had great improvements in learning English. It can be attributed to the availability of English language institutes and the widespread use of mass media like Internet, satellites and so on. In fact, English language institutes emphasize language use more than language usage. The above-mentioned factors might offer some reasons why the strategies used by Iranian language learners are different from those used by learners of other countries. In other words, language learning heavily depends on environmental factors and also individual differences such as age, motivation, and so on.

\section{Implications of the study}

As it was shown, Iranian language learners and those from other nationalities share some language learning strategies and differ in the use of other learning strategies. Such findings can be of use for both language teachers and material developers. Teachers can emphasize or teach those strategies which learners find practical and preferable to use. Material designers can also develop the language exercises in such a way to have the most practicality and benefit for language learners based on the preferred strategies.

\section{References}

Amini Farsani, M., Nikoopour, J., \& Kashefi Neishabouri, J. (2011). Language learning strategy preferences of Iranian EFL students. International conference on social science and humanity IPERD, 5, Singapore.

Bacon, S., \& Finnemann, M. (1992). Sex differences in self-reported beliefs about foreign language learning and authentic oral and written input. Language Learning, 42, 471-495. http://dx.doi.org/10.1111/j.1467-1770.1992.tb01041.x

Cohen, A. (1998). Strategies in learning and using a second language. London: Longman.

Farhady, H., \& Hedayati, H. (2009). Language assessment policy in Iran. Annual Review of Applied Linguistics, 29(1), 132-141. http://dx.doi.org/10.1017/S0267190509090114 
Fotovatian, S., \& Shokrpour, N. (2007). Comparison of the efficacy of reading comprehension strategies on Iranian university students' comprehension. Journal of College Reading and Learning, 37(2), 47-63.

Gardner, D., \& Miller, L. (Eds.). (1996). Tasks for independent language learning. Alexandria, VA: TESOL.

Green, J. M., \& Oxford, R. L. (1995). A closer look at learning strategies, L2 Proficiency and Gender. TESOL Quarterly, 29(2), 261-297. http://dx.doi.org/10.2307/3587625

Griffiths, C. \& Parr, J. M. (2001). Language learning strategies: Theory andperception. ELT Journal, 55(3), 247-254. http://dx.doi.org/10.1093/elt/55.3.247

Jafari, S. M., \& Shokrpour, N. (2012). The reading strategies used by Iranian ESP students to comprehend authentic expository texts in English. International Journal of Applied Linguistics and English Literature, 1(4), 102-114. http://dx.doi.org/10.7575/ijalel.v.1n.4p.102

Kafipour, R., Yazdani, M., Soori, A., \& Shookrpour, N. (2011). Vocabulary levels and vocabulary learning strategies of Iranian postgraduate studies. Studies in Literature and Language, 3(3), 64-71.

Liu, D. (2004). EFL proficiency, gender and language learning strategy use among a group of Chinese technological institute English majors. Annual Review of Education, Communication and Language Sciences. E. Journal, 1.

Myung-Cook, K. (2001). Language learning strategies and proficiency of Korean learners of Chinese. M. A. thesis, University of China, English Language Literature and Linguistics.

Oktay, A. (2009). The Role of Gender and Language Learning Strategies in Learning English, M. A. thesis, Middle East Technical University, Turkey.

Olivares-Cuhat, G. (2002). Learning strategies and achievement in the Spanish writing classroom: A case study. Foreign Language Annals, 35(5), 561-70. http://dx.doi.org/10.1111/j.1944-9720.2002.tb02724.x

Oxford, R. (1989). Strategy inventory for language learning (SILL). Retrieved on 23 Oct. 2012. from http://www.tu-chemnitz.dephil/IntenetGrammar/publications/info/sill.shtml.

Oxford, R. L. (1990). Language learning strategies: What every teacher should know. New York: Newbury House.

Oxford, R. (1992). Research on second language learning strategy. Annual Review of Applied Linguistics, 13, 175-187. http://dx.doi.org/10.1017/S0267190500002452

Oxford, R. L. (1993). Gender differences in styles and strategies for language learning: What do they mean? Should we pay attention? In J. Alatis (Ed.), Strategic interaction and Language acquisition: Theory, practice, and research (pp.541-557) Washington, DC: Georgetown University Press.

Riazi, A., \& Rahimi, M. (2005). Iranian EFL learners' pattern of language learning use. The Journal of Asia TEFL, 2(1), 103-129.

Rubin, J. (1975). What the good language learner can teach us. TESOL Quarterly, 9, 41-55. http://dx.doi.org/10.2307/3586011 


\section{Macrothink}

Journal of Studies in Education

ISSN 2162-6952

2013, Vol. 3, No. 1

Rubin,J.(1987). Learning strategies: Theoretical assumption, research history and typology. In A. Wenden and J. Rubin(Eds.), Learning strategies in language learning (pp.15-30). Englewood, NJ: Prentice-Hall

Seddigh, F., \& Shokrpour, N. (2012). Vocabulary learning strategies of medical students at Shiraz University of Medical University. English Language Teaching, 5(2), 160-173. http://dx.doi.org/10.5539/elt.v5n2p160

Shokrpour, N., \& Nasiri, E. (2011). The use of cognitive and metacognitive reading strategies by Iranian IELTS test takers in the reading section of the test. European Journal of Social Sciences, 22(1), 126-134.

Shokrpour, N., \& Mahbudi, A. (2011). Gender and reading comprehension strategies. Language Forum, 37(1), 103-116.

Siew-Yen, O. (2004). English language learning strategies used by the sophomore students of a technology university. M.A. Thesis, University of Taiwan.

Sy, B. M. (1994). Sex differences and language learning strategies. Paper presented at the11th Conference of Teachers of English to Speakers of Other Languages of the Republic of China, Taiwan.

Tamada, Y. (1996). The review of studies related to language learning strategies. ERIC: Document Reproduction Service. Washington, DC: Department of Education. [ERIC: Document Repro].

Tercanlıoğlu, L. (2004). Exploring gender effect on adult foreign language learning strategies [Electronic version]. Issues in Educational Research, 14, 181-193.

Tran, T. V. (1988). Gender differences in English language acculturation and learning strategies among Vietnamese adults aged 40 and over in the United States. Gender Roles, 19, 747-758. http://dx.doi.org/10.1007/BF00288990

Wharton, G. (2000). Language learning strategy use of bilingual foreign language learners in Singapore. Language Learning, 50(2), 203-43. http://dx.doi.org/10.1111/0023-8333.00117

Willing, K. (1988). Learning styles in adult migrant education. Sydney: Macquarie University.

Zarei, E., Shokrpour, N., Nasiri, E., \& Kafipour, R. (2012). Self esteem and academic success as influenced by reading Strategies. English Language Teaching, 5(2), 17-26. http://dx.doi.org/10.5539/elt.v5n2p17 